\title{
Mice Lacking Specific Nicotinic Acetylcholine Receptor Subunits Exhibit Dramatically Altered Spontaneous Activity Patterns and Reveal a Limited Role for Retinal Waves in Forming ON and OFF Circuits in the Inner Retina
}

\author{
Anu Bansal, ${ }^{1,2}$ Joshua H. Singer, ${ }^{1}$ Bryan J. Hwang, ${ }^{1,2}$ Wei Xu, ${ }^{3}$ Art Beaudet, ${ }^{3}$ and Marla B. Feller ${ }^{1}$ \\ 1Synapse Formation and Function Unit, National Institute of Neurological Disorders and Stroke, National Institutes of \\ Health, and 2 Howard Hughes Medical Institute-National Institutes of Health Research Scholars Program, Bethesda, \\ Maryland 20892, and ${ }^{3}$ Department of Molecular and Human Genetics, Baylor College of Medicine, Houston, Texas 77030
}

\begin{abstract}
Before phototransduction, spontaneous activity in the developing mammalian retina is required for the appropriate patterning of retinothalamic connections, and there is growing evidence that this activity influences the development of circuits within the retina itself. We demonstrate here that the neural substrate that generates waves in the mouse retina develops through three distinct stages. First, between embryonic day 16 and birth [postnatal day $0(\mathrm{PO})$ ], we observed both large, propagating waves inhibited by nicotinic acetylcholine receptor (nAChR) antagonists and small clusters of cells displaying nonpropagating, correlated calcium increases that were independent of $\mathrm{nAChR}$ activation. Second, between P0 and P11, we observed only larger propagating waves that were abolished by toxins specific to $\alpha 3$ and $\beta 2$ subunit-containing nAChRs. Third, between P11 and P14 (eye opening) we observed propagating activity that was abolished by ionotropic glutamate receptor antagonists. The time course of this developmental shift was dramatically altered in retinas from mice lacking the $\beta 2 \mathrm{nAChR}$ subunit or the $\beta 2$ and $\beta 4$ subunits.
\end{abstract}

These retinas exhibited a novel circuit at P0, no spontaneous correlated activity between $\mathrm{P} 1$ and $\mathrm{P} 8$, and the premature induction at P8 of an ionotropic glutamate receptor-based circuit. Retinas from postnatal mice lacking the $\alpha 3 \mathrm{nAChR}$ subunit exhibited spontaneous, correlated activity patterns that were similar to those observed in embryonic wild-type mice. In $\alpha 3-/-$ and $\beta 2-/-$ mice, the development and distribution of cholinergic neurons and processes and the density of retinal ganglion cells (RGCs) and the gross segregation of their dendrites into ON and OFF sublaminae were normal. However, the refinement of individual RGC dendrites is delayed. These results indicate that retinal waves mediated by $\mathrm{nAChRs}$ are involved in, but not required for, the development of neural circuits that define the ON and OFF sublamina of the inner plexiform layer.

Key words: retinal waves; calcium imaging; visual system development; cholinergic amacrine cells; nicotinic receptor subunits; spontaneous activity
In many regions of the developing nervous system, spontaneous calcium and electrical signals have been observed even before neural circuits are fully formed or sensory transduction is possible (Yuste, 1997). This activity may promote the functional maturation of neural circuits. For example, in the developing visual system, before eye opening, retinal ganglion cells (RGCs) spontaneously fire periodic bursts of action potentials that propagate across the ganglion cell layer (Wong, 1999). This highly correlated, propagating retinal activity, termed "retinal waves," is mediated at least in part by synaptic transmission. Spontaneous retinal activity has been implicated in directing the refinement of connections between RGC axons and their thalamic targets in the lateral geniculate nucleus (Penn et al., 1998; Shatz and Stryker, 1988; Chapman, 2000) (but see Cook et al., 1999). Spontaneous retinal activity has been implicated also in the establishment of orientation selectivity

\footnotetext{
Received April 14, 2000; revised June 27, 2000; accepted July 26, 2000.

This work was supported by National Institutes of Health Intramural Research Program and National Institutes of Health Grant DA-12661 (W.X. and A.B.). A.B. and B.J.H. were supported by the Howard Hughes Medical Institute-National Institutes of Health Research Scholars Program. J.H.S. was supported by a National Institute of General Medical Sciences pharmacology research associate training fellowship. We thank the National Institute of Neurological Disorders and Stroke Light Imaging Facility for use of a confocal microscope, Rukmini Mirotznik for assistance with anatomical analysis, R. Mirotznik, Ralph Nelson, and Jeff Diamond for critical reading of this manuscript, Margaret Coulombe for assistance with genotyping, Michael McIntosh for kindly donating the conotoxins, and Avi orr-Urtreger for providing access to the $\beta 4-/-$ mouse.

Correspondence should be addressed to Marla B. Feller, Synapse Formation an Function Unit, National Institute of Neurological Disorders and Stroke, National Institutes of Health, 36 Convent Drive, 36/5B16, Bethesda, MD 20892-4126. E-mail: marla@codon.nih.gov.

Copyright (c) 2000 Society for Neuroscience $0270-6474 / 00 / 207672-10 \$ 15.00 / 0$
}

in primary visual cortex (Chapman and Godecke, 2000), although other cues may be involved in the establishment of ocular dominance columns (Crowley and Katz, 1999).

Spontaneous neural activity may also influence the development of the retina itself. Although a general blockade of action potentials with intraocular injections of tetrodotoxin had little effect on the dendritic structure of RGCs in both embryonic (Campbell et al., 1997) and postnatal cat retina (Wong et al., 1991), manipulations of neurotransmitter systems providing synaptic input to ganglion cells had more profound effects on RGC anatomy and function. For example, Sernagor and Grzywacz (1996) demonstrated that blockade of retinal wave activity in turtle retina with intraocular injection of the general nicotinic acetylcholine receptor (nAChR) antagonist D-tubocurarine prevented the dark-rearing-induced changes in RGC receptive fields. RGC dendrites are therefore unable to respond to altered sensory experience in the absence of spontaneous correlated activity. In another example, Lau et al. (1992) demonstrated that blockade of NMDA receptors before eye opening increase the spine density of RGCs in hamster. In addition, Bodnarenko and Chalupa (1993) and Bodnarenko et al. (1995) demonstrated that the segregation of RGC dendrites into $\mathrm{ON}$ and OFF sublamina requires glutamatergic neurotransmission from bipolar cells.

The fact that both cholinergic and glutamatergic neurotransmission are implicated in the activity-dependent development of the retina is of significant interest, because retinal waves are modulated differentially by these two neurotransmitter systems during postnatal development (Catsicas et al., 1998; Wong et al., 1998, 2000; Wong, 1999; Sernagor et al., 2000; Zhou and Zhao, 2000). For example, during the first 10 postnatal days (P0-P10) in ferret, both 
the generation and propagation of retinal waves are blocked by neuronal nAChR antagonists (Feller et al., 1996). In ferret retinas older than P15, waves are insensitive to $\mathrm{AChR}$ antagonists and are blocked instead by ionotropic glutamate receptor antagonists (Wong et al., 2000). The timing of this developmental switch to glutamatergic transmission is correlated with the appearance of bipolar cell terminals in the inner plexiform layer (IPL) (Miller et al., 1999). It has not been demonstrated previously whether the transition from cholinergic to glutamatergic waves required nAChR-mediated retinal activity.

Here we show that the circuitry that mediates retinal waves in the neonatal mouse retina makes a similar transition from nAChRmediated to ionotropic glutamate receptor-mediated transmission during postnatal development. As in the ferret retina (Penn et al., 1998), the functional nAChR receptors mediating waves in mice contain $\alpha 3$ and $\beta 2$ subunits. We make use of genetically altered mice lacking these nAChR subunits (Xu et al., 1999a,b) to assay their contribution to spontaneous activity in the developing retina. Mice lacking the $\alpha 3$ subunit showed retinal wave activity with altered spatiotemporal properties, whereas mice lacking the $\beta 2$ subunit had no detectable wave activity during the first postnatal week. The absence of cholinergic-mediated waves in $\beta 2-/-$ mice induces them to make a precocious transition to ionotropic glutamate receptor-mediated waves. We then examined the contribution of nAChR-mediated waves to the maturation of anatomical circuits in the inner retina by comparing in $\beta 2-/-$ and normal mice the distribution of cholinergic processes and the stratification of RGC dendritic arbors.

\section{MATERIALS AND METHODS}

Retinal preparation. All procedures were performed in accordance with approved animal use protocols at National Institutes of Health. Retinas were isolated from newborn mice (P0-P13) that had been deeply anesthetized with halothane and then decapitated. They were placed ganglion cell layer-up in a temperature-controlled chamber $\left(30^{\circ} \mathrm{C}\right.$; Warner Systems $)$ mounted on the stage of an upright microscope (Axioskop; Zeiss, Thornwood, NY) and perfused continuously with artificial CSF (ACSF; in mM: $119 \mathrm{NaCl}, 2.5 \mathrm{KCl}, 1.3 \mathrm{MgCl}_{2}, 1.0 \mathrm{KH}_{2} \mathrm{PO}_{4}, 2.5 \mathrm{CaCl}_{2}, 26.2 \mathrm{NaHCO}_{3}$, and 11 D-glucose) bubbled with $95 \% \mathrm{O}_{2}$ and $5 \% \mathrm{CO}_{2}$.

Fluorescence imaging. Isolated retinas were incubated with $10 \mu \mathrm{M}$ fura-2 AM (Molecular Probes, Eugene, OR) in ACSF containing 1\% DMSO and $0.02 \%$ pluronic acid for $2-6 \mathrm{hr}$ in an oxygenated chamber at $28^{\circ} \mathrm{C}$. All experiments were conducted with $380 \mathrm{~nm}$ illumination under a $10 \times$ water immersion objective (Olympus Optical, Tokyo, Japan). Images were acquired with a silicon-intensified target camera (MIT 300; Dage, Michigan City, IN). An initial background frame was acquired and was subtracted on a pixel-by-pixel basis from all subsequent frames to create a difference image. The difference image was averaged over four video frames, giving a time resolution of $120 \mathrm{msec} /$ frame. Images were processed by a digital video processor (DV P-32; Instrutech, Port Washington, NY) and recorded onto s-videotape (Panasonic). The average fluorescence intensity over a $200 \mu \mathrm{m}^{2}$ area was monitored on each retina to determine the frequency and peak amplitude of the fractional changes in fluorescence, $\Delta \mathrm{F} / \mathrm{F}$. Recorded waves were digitized and analyzed on an Apple (Cupertino, CA) Macintosh computer using NIH Image software to determine the area, frequency, and velocity.

Electrophysiology. Whole-cell voltage- or current-clamp recordings were made using an Axopatch 200B amplifier and pClamp6 software (Axon Instruments, Foster City, CA). The amplitude of postsynaptic currents (PSCs) was taken as the maximum current recorded during a compound event. $V_{\text {hold }}$ was $-60 \mathrm{mV}$. The intracellular solution consisted of (in $\mathrm{mM}$ ): 98.3 potassium gluconate, $1.7 \mathrm{KCl}, 0.6 \mathrm{EGTA}, 5 \mathrm{MgCl}_{2}, 2 \mathrm{Na}_{2}$-ATP, 0.3 GTP, and 40 HEPES, pH 7.25, with $\mathrm{KOH}$. The calculated $E_{\mathrm{Cl}}$ was $-60 \mathrm{mV}$.

Pharmacology. All pharmacological agents (RBI/Sigma, St. Louis, MO) were dissolved in ACSF and bath-applied to retina. Conotoxins were provided by M. McIntosh, University of Utah, Salt Lake City, UT (Cartier et al., 1996; Luo et al., 1998). To facilitate peptide penetration into retinal tissue, the retinas were incubated in $2 \mathrm{mg} / \mathrm{ml}$ collagenase/dispase (Boehringer Mannheim, Indianapolis, IN) for $10 \mathrm{~min}$ at $30^{\circ} \mathrm{C}$. Although this treatment was found to alter the spatiotemporal properties of waves in normal mice, primarily by restricting the size of propagating waves $(n=3)$, this treatment was necessary to allow conotoxins to penetrate into the tissue (Fig. 1C). A similar collagenase treatment was used to load retinas from animals older than P5 with fura-2 AM (see Fig. 3C). All drug effects were reported as mean $\pm \mathrm{SD}$. Significance was tested using a Student's $t$ test unless noted otherwise (Sigmastat).

Immunohistochemistry. Mice older than P2 were perfused with a $4 \%$ solution of paraformaldehyde (Sigma) in $0.1 \mathrm{M}$ phosphate buffer for 10 min. For P2 preparations, eyes were immersion-fixed in $4 \%$ paraformaldehyde in $0.1 \mathrm{M}$ phosphate buffer for $30 \mathrm{~min}$. Eyecups were post-fixed for an additional $60 \mathrm{~min}$. Eyes were cryoprotected in $30 \%$ sucrose in Trisbuffered saline and were cut into $14 \mu \mathrm{m}$ transverse sections on a cryostat. Sections were mounted and permeabilized in a solution containing (in \%): 20 normal donkey serum, 5 sucrose, 0.5 Triton X-100, and 0.001 sodium azide for $2 \mathrm{hr}$. Primary antibodies to choline acetyltransferase (anti-ChAT, generated in goat; Chemicon, Temecula, CA) and the vesicular acetylcholine transporter (anti-VAChT, generated in rabbit; a gift from S. Landis, National Institutes of Health, Bethesda, MD) were diluted into this solution at 1:100 and 1:1000, respectively. Sections were incubated in primary antibodies at $4^{\circ} \mathrm{C}$ for $24 \mathrm{hr}$ and fluorescence-labeled secondary antibodies for $30 \mathrm{~min}$ (1:50 fluorescein-conjugated anti-goat and 1:150 rhodamine red-X-conjugated anti-rabbit; Jackson ImmunoResearch, West Grove, PA). The following controls were performed to ensure primary and secondary antibody specificity: (1) incubation with no primary and then one or both secondary antibodies yielded no specific staining; and (2) incubation with one primary antibody and both secondary antibodies or both primary antibodies and one secondary antibody resulted in staining that was indistinguishable from incubation with a single primary and animal-matched secondary antibody combination.

Ganglion cell morphology. RGCs were filled while recording with pipettes containing $0.4-0.5 \%$ Lucifer yellow dissolved in internal solution. Retinas were then fixed in $4 \%$ paraformaldehyde, incubated in $10 \mu \mathrm{M}$ 4,6-diamidino-2-phenylindole (DAPI) in phosphate buffer solution to label cell nuclei, mounted on slides, and viewed on either a deconvolution microscope (Scanalytics Cellscan, Axiophot) or a confocal microscope (Zeiss 410). RGCs were identified on the basis of dendritic morphology, soma size, presence of a large $\mathrm{Na}^{+}$current, and, in some cases, presence of an axon. Dendritic stratifications were measured from 3-D reconstructions (NIH Image and Metamorph Software; Universal Imaging, West Chester, PA). The location and width (taken at half-maximum) of these stratifications were normalized to the width of the IPL, which was obtained by measuring the distance between DAPI-labeled nuclei in the ganglion cell layer and inner nuclear layer.

Ganglion cell dendrites were also visualized after retrograde transport of $1,1^{\prime}$-dioctadecyl-3,3,3',3'-tetramethyl indocarbocyanine percholate (DiI) crystals applied to the optic nerves of animals that had been perfusion- and post-fixed with $4 \%$ paraformaldehyde. Again, RGCs were reconstructed using a confocal microscope, and dendritic stratifications were counted from the 3-D reconstructions (NIH Image and Metamorph Software; see Fig. 5A2). The density of RGCs was measured by dividing the number of cell bodies contained in a single $z$ section of the ganglion cell layer by the total area of that section.

Genotyping. Genotyping of mice lacking the $\alpha 3, \beta 2$, and $\beta 4$ subunits was done by PCR with primer sequences as previously described ( $\mathrm{Xu}$ et al., $1999 \mathrm{a}, \mathrm{b}) . \alpha 3-/-$ mice were generated in litters containing $\alpha 3-/-, \alpha 3+/-$, and $\alpha 3+/+$ offspring. $\beta 2-/-\beta 4-/-$ mice were raised on a $\beta 2-/-$ homozygote background and generated litters containing $\beta 4-/-, \beta 4+/-$, and $\beta 4+/+$ offspring. These mice were back-crossed at least six generations into the C57black6 strain; C57black6 mice were used for comparison in all experiments. DiI labeling was also conducted in $\beta 2-/-\beta 4+/+$ and $\beta 2+/+\beta 4+/+$ littermate pairs.

\section{RESULTS}

\section{Waves in P0-P7 mice are mediated by nAChRs containing $\alpha 3$ and $\beta 2$ subunits}

Experiments were conducted on retinas isolated acutely from newborn mice (P0-P13) and incubated in the calcium indicator fura-2 AM. The spatial distribution and time course of spontaneous changes in intracellular calcium concentration $\left(\left[\mathrm{Ca}^{2+}\right]_{i}\right)$ in the ganglion cell layer were assessed by real-time fluorescence imaging and represented by the fractional change in fluorescence $\Delta \mathrm{F} / \mathrm{F}$. Periodic changes in $\left[\mathrm{Ca}^{2+}\right]_{\mathrm{i}}$ are associated with membrane depolarizations driven by barrages of synaptic inputs (Feller et al., 1996) and therefore can be interpreted as a measure of cell electrical activity.

Retinal waves recorded in mice have spatiotemporal properties similar to those previously characterized in ferret (Feller et al., 1996, 1997) and chick (Wong et al., 1998; Sernagor et al., 2000). Waves initiate in random locations and propagate across the retina, stopping at well-defined boundaries (Fig. $1 A$ ). These boundaries are determined in part by a "refractory period" that we define as the period after a wave has passed through a region of the retina during which another wave cannot propagate through that same region. Using a previously described method (Feller et al., 1996), we calculated the wave refractory period in mice to be 25-35 sec (data not shown; $n=170$ wave pairs, four retinas), shorter than the 40-50 sec refractory period in ferrets (Feller et al., 1996).

Bath application of $\mathrm{nAChR}$ antagonists D-tubocurarine chloride (curare, 50-100 $\mu \mathrm{M} ; n=11$ retinas) and dihydro- $\beta$-erythroidine (1 $\mu \mathrm{M} ; n=7$ retinas) blocked all spontaneous increases in $\left[\mathrm{Ca}^{2+}\right]_{\mathrm{i}}$ 
A.

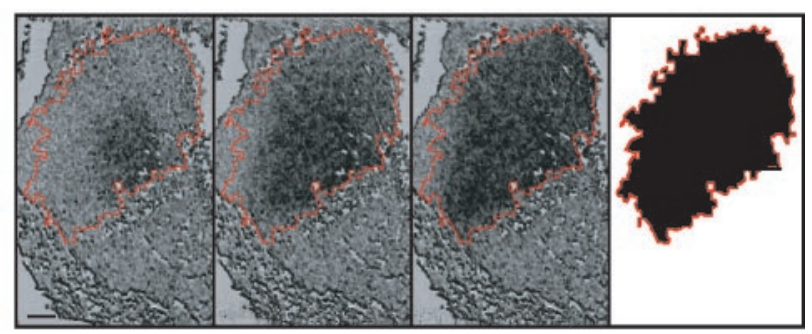

B.
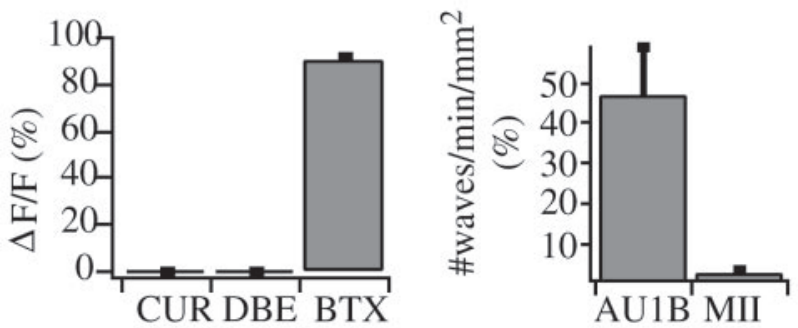

Figure 1. Retinal waves in normal mice are mediated by $\mathrm{nAChRs}$ containing $\alpha 3$ and $\beta 2$ subunits. $A$, Time evolution of a single retinal wave visualized with fluorescence imaging. Decreases in fura-2 fluorescence associated with the increased calcium evoked by waves are shown at successive $0.5 \mathrm{sec}$ intervals. The last frame represents the "domain" of the wave, defined as the total area of tissue covered by a single wave. $B$. Spontaneous activity is blocked by toxins specific to $\mathrm{nAChRs}$ containing the $\alpha 3$ subunit. Left, Effects of 50-100 $\mu \mathrm{M}$ curare $(C U R), 2 \mu \mathrm{M}$ dihydrobetaerthroidine $(D B E)$, and $200 \mathrm{nM} \alpha$-bungarotoxin $(B T X)$ on the fractional change in fluorescence, $\Delta \mathrm{F} / \mathrm{F}$, averaged over $100 \mu \mathrm{m}^{2}$ regions of $\mathrm{P} 0-\mathrm{P} 6$ retinas. Right, Effects of $\alpha$-conotoxin-AU1B $(A U 1 B)$ and $\alpha$-conotoxin MII $(M I I)$ on the number of waves per minute per square millimeter. The collagenase treatment necessary for peptide penetration restricted wave propagation (see Materials and Methods) and made $\Delta \mathrm{F} / \mathrm{F}$ measurements in a small region a poor reflection of the overall activity level. Therefore, the conotoxin effects on wave activity were measured by counting the number of waves observed in the total imaged area in a $10 \mathrm{~min}$ period. Scale bar, $100 \mu \mathrm{m}$.

associated with retinal waves (Fig. $1 B$ ). This indicates that retinal waves require $\mathrm{nAChR}$-mediated synaptic transmission, a result that has been observed in rabbit (Masland, 1977; Zhou, 1998), turtle (Sernagor and Grzywacz, 1999), and ferret (Feller et al., 1996) but not chick (Catsicas et al., 1998; Wong et al., 1998; Sernagor et al., 2000).

Nicotinic AChRs found in the CNS are either homomultimers consisting entirely of $\alpha 7$ subunits or heteromultimers containing a combination of $\alpha$ and $\beta$ subunits (Sargent, 1993; McGehee and Role, 1995; Role and Berg, 1996). In heterologous expression systems, $\alpha 3$ subunits form functional nAChRs only in the presence of either the $\beta 2$ or $\beta 4$ subunit (Sargent, 1993; Role and Berg, 1996). In situ hybridization (Zoli et al., 1995) and antibody labeling have localized these subunits to the retina (Aizenman et al., 1990; Hamassaki-Britto et al., 1994). We used high-affinity antagonists selective for nAChRs containing particular subunits or subunit combinations to identify the functional receptors mediating waves. Bath application of $\alpha$-bungarotoxin (200 nM), a toxin with a high affinity for $\mathrm{nAChRs}$ containing the $\alpha 7$ subunit, only weakly attenuated periodic $\left[\mathrm{Ca}^{2+}\right]_{\mathrm{i}}$ increases $(\Delta \mathrm{F} / \mathrm{F}=90 \pm 2 \%$ of control; $n=$ 3 , three mice; Fig. $1 B$ ). Thus, nAChRs containing the $\alpha 7$ subunit do not appear to be required for wave generation. On the other hand, $\alpha$-conotoxin-MII $(1 \mu \mathrm{M})$ and $\alpha$-conotoxin-AU1B $(1-10 \mu \mathrm{M})$, toxins that preferentially block $\alpha 3 \beta 2$ and $\alpha 3 \beta 4 \mathrm{nAChRs}$, respectively (Cartier et al., 1996; Luo et al., 1998), dramatically reduced wave frequency ( $\alpha$-conotoxin-MII, $5 \pm 3 \%$ of control; $n=3$, three mice; $\alpha$-conotoxin-AU1B, $45 \pm 10 \%$ of control; $n=5$, two mice; $p<0.001$; Fig. $1 B$ ). Although the specificity of these toxins may be compromised at the high concentrations used here (Cartier et al., 1996), and their specificity has not been determined for mouse
nAChRs, the maximal inhibition by $\alpha$-conotoxin-MII indicates that in mice, as in ferrets (Penn et al., 1998), an $\alpha 3$ - and $\beta 2$-containing $\mathrm{nAChR}$ is the most critical to retinal waves.

The potential lack of specificity of conotoxins as well as the growing evidence that $\mathrm{nAChRs}$ in vivo may contain more than one subunit from each of the $\alpha$ and $\beta$ families indicate that our pharmacological studies do not precisely define the role that $\alpha 3$ and $\beta 2$ subunits play in retinal wave generation. Hence, we studied the spontaneous retinal activity in transgenic mice lacking either the $\alpha 3$ or $\beta 2 \mathrm{nAChR}$ subunit or both the $\beta 2$ and $\beta 4$ subunits. The gross phenotypes of the $\alpha 3-/-$ (Xu et al., 1999a), $\beta 2-/-$, and $\beta 2-/-\beta 4$ $-/-(\mathrm{Xu}$ et al., 1999b) mice have been described previously. Generally, $\alpha 3-/-$ and $\beta 2-/-\beta 4-/-$ mice have similar phenotypes, exhibiting a loss of function of the autonomic nervous system, delayed eye opening, and high mortality after the first postnatal week (Xu et al., 1999a,b). The $\beta 2-/-$ mice, however, although exhibiting a normal phenotype, show abnormal passive avoidance behavior (Picciotto et al., 1995), increased neurodegeneration with aging (Zoli et al., 1999), and a reduced antinociceptive response to nicotine (Marubio et al., 1999).

\section{Correlated activity in the $\alpha 3-/-$ retina has altered spatiotemporal properties mediated by the extension of an embryonic wave-generating mechanism}

Retinas from mice lacking the $\alpha 3$ subunit exhibited spontaneous correlated activity different from that of wild-type retinas. We have classified the spontaneous activity in $\alpha 3-/-$ mice into two categories: large propagating waves (each wave covering $>0.075 \mathrm{~mm}^{2}$ ) and small $\left(<0.075 \mathrm{~mm}^{2}\right)$, co-active domains (Fig. $\left.2 A, B\right)$. Note that this distinction of size is not absolute: all events $<0.025 \mathrm{~mm}^{2}$ (represented by the 1st bin in the summary histograms of Fig. $2 B$ ) correspond to a simultaneous increase in $\left[\mathrm{Ca}^{2+}\right]_{\mathrm{i}}$; all events $>0.075$ $\mathrm{mm}^{2}$ (4th-40th bins of Fig. $2 B$ ) correspond to propagating events; and events between the size of 0.025 and $0.075 \mathrm{~mm}^{2}$ (2nd and 3rd bins of Fig. $2 B$ ) represent a mixture of nonpropagating and propagating events.

Consistent with the idea that propagating waves are mediated by synaptic transmission, whole-cell recordings from RGCs in $\alpha 3-/-$ mice reveal periodic PSCs comparable in size and frequency with those of littermate controls (Fig. $2 C$ ). Also, as in wild-type control retinas, the large propagating waves $\left(>0.075 \mathrm{~mm}^{2}\right)$ in $\alpha 3-/-$ retinas were blocked by the general $\mathrm{nAChR}$ antagonist curare $(100$ $\mu \mathrm{M} ; n=3$; Fig. $2 A$ ), suggesting that other nAChR subunits compensate for the missing $\alpha 3$ subunit; we considered first the $\alpha 7$ subunit-containing nAChRs.

Although the $\alpha 7$ subunit is expressed in the retina (HamassakiBritto et al., 1994), it is not thought to be functional on adult RGCs (Aizenman et al., 1990; Baldridge, 1996). In agreement with these observations, bath application of $\alpha$-bungarotoxin did not decrease significantly the magnitude of $\Delta \mathrm{F} / \mathrm{F}$ (data not shown, $66.7 \pm 9.6 \%$ of control in $\alpha 3-/-$ mice; $n=3 ; 79.1 \pm 5.3 \%$ in $\alpha 3+/+$ mice; $n=$ $4 ; p=0.281$ ) indicating that waves in $\alpha 3-/-$ mice are not mediated by increased numbers of $\alpha 7$ subunit-containing nAChRs. Other candidates for compensatory receptor subunits are the $\alpha 5$ and $\alpha 6$ subunits. They are expressed in the retina (Zoli et al., 1995; Vailati et al., 1999) and have been shown to form functional nAChRs with $\beta 2, \beta 3$, and $\beta 4$ subunits (Ramirez-Latorre et al., 1996). Note that these other subunits may form functional nAChRs in combination with $\alpha 3$ and $\beta 2$ subunits in normal mice, in which case the compensation may involve upregulation of subunits that are normally expressed.

In addition to propagating waves, $\alpha 3-/-$ mice supported a pattern of activity previously unobserved in the developing, postnatal retina. This activity was characterized by spontaneous increases in $\left[\mathrm{Ca}^{2+}\right]_{\mathrm{i}}$ correlated across small regions containing only $10-20$ cells $\left(\sim 0.025-0.075 \mathrm{~mm}^{2}\right)$. None of the events observed in wild-type mice is limited to such a small region of the retina (Fig. $2 \mathrm{~B}$, red arrow). These simultaneous $\left[\mathrm{Ca}^{2+}\right]_{\mathrm{i}}$ increases did not propagate away from initiation sites, and their appearance was not sensitive to bath application of curare ( 0 of 29 waves in curare were 
A.

$$
\mathrm{P} 2
$$

$\alpha 3+/+$

Control
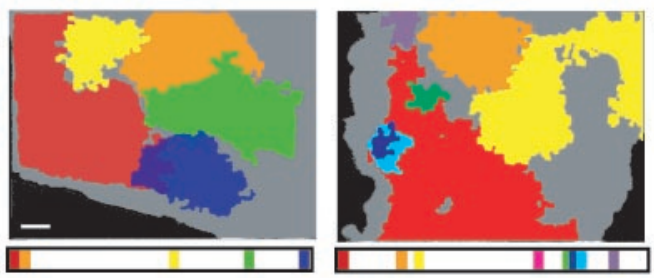

$\mathrm{P} 2$

$\alpha 3-1-$

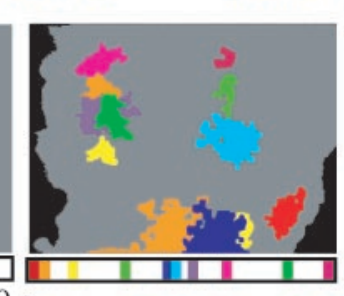

$90 \mathrm{~s}$

0

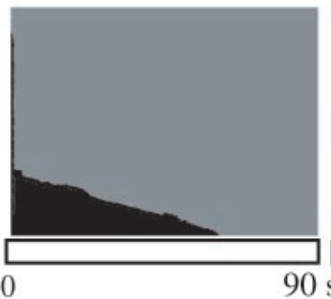

E17

normal
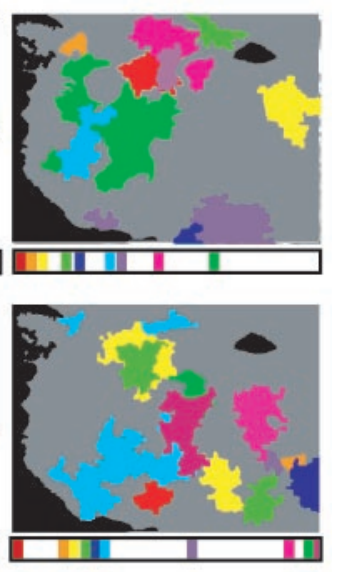

B.
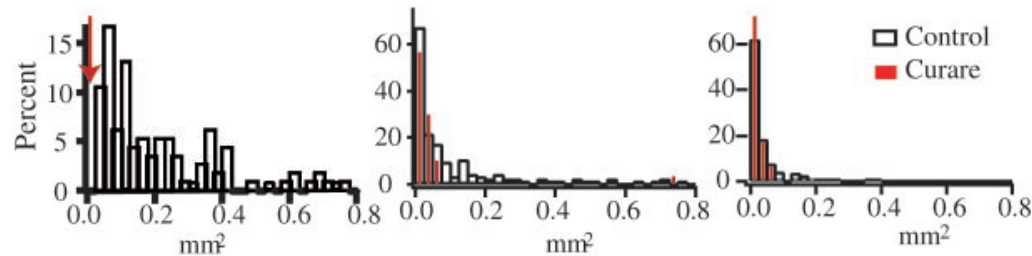

C.

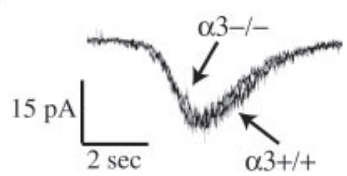

Peak amplitude (pA)

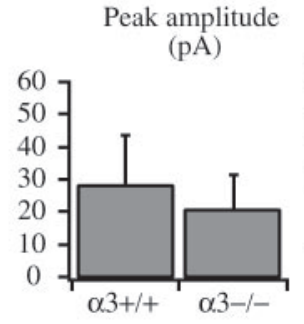

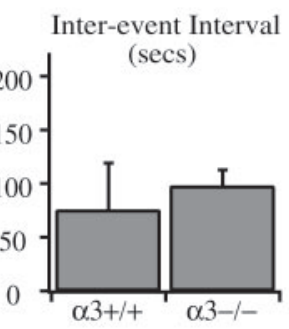

Figure 2. Waves in $\alpha 3-/-$ mice have altered spatiotemporal properties. $A$, Retinal waves of postnatal wild-type $(P 2 \alpha 3+/+), \alpha 3-/-(P 2)$, and embryonic (E17 normal) retinas. Each frame summarizes $90 \mathrm{sec}$ of activity in control ACSF (top row) and in $100 \mu \mathrm{M}$ D-tubocurarine (bottom row). Gray background represents the total retinal surface labeled with fura-2 AM. Each color corresponds to individual domains with a color-coded time bar below each frame to indicate the time of occurrence of each wave. Scale bar, $100 \mu \mathrm{m}$. $B$, Normalized distribution of domain sizes for the three classes of retinas pictured in $A$ in control ACSF (open bars) and in D-tubocurarine (red lines). Bin size is $0.025 \mathrm{~mm}^{2} . \alpha 3+/+$ mice, $n=114$ waves in control solutions, four retinas, three mice; $\alpha 3-/-$ mice, $n=139$ waves in control solutions; $n=93$ in D-tubocurarine, three retinas, three mice; embryonic normal mice, $n=161$ waves in control solutions; $n=30$ in D-tubocurarine, three retinas, two mice. $C$, Retinal ganglion cells from $\alpha 3-/-$ mice have periodic compound PSCs comparable with those of $\alpha 3+1+$ mice. Left, PSC recorded by whole-cell voltage clamp of RGCs in $\alpha 3-/-$ and $\alpha 3+1+$ mice. Right, PSC peak amplitudes and inter-event intervals for $\alpha 3+/+(9$ cells, 4 mice) and $\alpha 3-/-(9$ cells, 3 mice $)$ mice. large compared with 52 of 157 events in control; $n=3$ retinas, Fig. $2 A, B$, second column, bottom). We considered the possibility that these events are mediated by the activation of $\mathrm{GABA}_{\mathrm{A}}$ receptors, a situation that would be similar to the compensation seen in developing spinal cord (Chub and O'Donovan, 1998; Milner and Landmesser, 1999). However, these small events were not sensitive to $100 \mu \mathrm{M}$ picrotoxin, a $\mathrm{GABA}_{\mathrm{A}}$ receptor antagonist $(85 \pm 5 \%$ of control $\Delta \mathrm{F} / \mathrm{F}$ in $\alpha 3-/-$ mice; $n=2 ; 87.5 \pm 3.5 \%$ in $\alpha 3+/+$ mice; $n=2$; includes small and large events), raising the possibility that these correlated increases in $\left[\mathrm{Ca}^{2+}\right]_{\mathrm{i}}$ are nonsynaptic in origin.

The changes in the spatiotemporal properties of all spontaneous activity in $\alpha 3-/-$ mice are summarized in Table 1 . In comparison with littermate controls, the interval between waves and the interval between initiations were approximately halved in $\alpha 3-/-$ mice. However, although the interval between events decreased, the speed of wavefront propagation was comparable, indicating that the intercellular coupling responsible for the propagation of the activity is not likely to have changed. Interestingly, neither propagating waves nor the smaller regions of simultaneous $\left[\mathrm{Ca}^{2+}\right]_{\mathrm{i}}$ increases in $\alpha 3-/-$ mice consistently respected refractory boundaries defined by previous waves as observed in wild-type mice.

The above results imply that in $\alpha 3-/-$ mice there are two distinct mechanisms that underlie spontaneous generation of correlated activity in the retina. The mechanism underlying the gen-

Table 1. Summary of spatiotemporal properties (no. waves/no. experiments/no. mice)

\begin{tabular}{|c|c|c|c|c|}
\hline Genotype & Age & $\begin{array}{l}\text { Inter-event Interval } \\
\text { (sec/wave) }\end{array}$ & Speed $(\mu \mathrm{m} / \mathrm{sec})$ & $\begin{array}{l}\text { Initiation interval } \\
\left(\mathrm{sec} / \text { wave initiations per } \mathrm{mm}^{2}\right)\end{array}$ \\
\hline$+/+$ & $\mathrm{P} 2$ & $120.8 \pm 9.0 \quad(114 / 9 / 4)$ & $165.6 \pm 26.2(20 / 4 / 4)$ & $25.2 \pm 8.0(58 / 3 / 3)$ \\
\hline$+/+$ & $\mathrm{E} 17$ & $29.9 \pm 10.0(76 / 3 / 3)$ & $125.3 \pm 3.5(15 / 3 / 3)$ & $\begin{array}{c}\text { Control: } 3.4 \pm 0.9(139 / 3 / 3) \\
\text { Curare: } 7.5 \pm 4.7(94 / 3 / 3)\end{array}$ \\
\hline$\alpha 3-/-$ & $\mathrm{P} 0-\mathrm{P} 3$ & $53.1 \pm 7.6(57 / 6 / 4)$ & $143.2 \pm 18.7(15 / 3 / 3)$ & $\begin{array}{l}\text { Control: } 13.4 \pm 3.3(40 / 3 / 2) \\
\text { Curare: } 39.5 \pm 9.7(30 / 3 / 2)\end{array}$ \\
\hline$\beta 2-/-\beta 4-/-$ & $\mathrm{P} 0$ & $34.3 \pm 7.9(60 / 4 / 3)$ & $165.4 \pm 12.1(15 / 3 / 3)$ & $9.7 \pm 2.8(147 / 3 / 3)$ \\
\hline
\end{tabular}

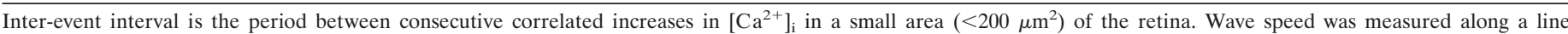

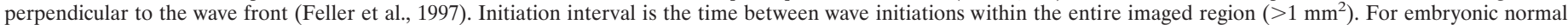
mice and $\alpha 3-/-$ mice, the initiation intervals in the presence of curare are also listed. 
A.

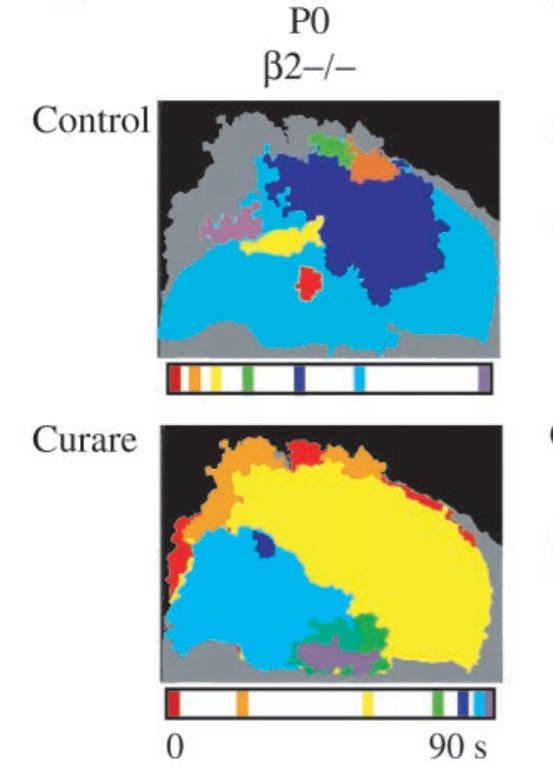

B.

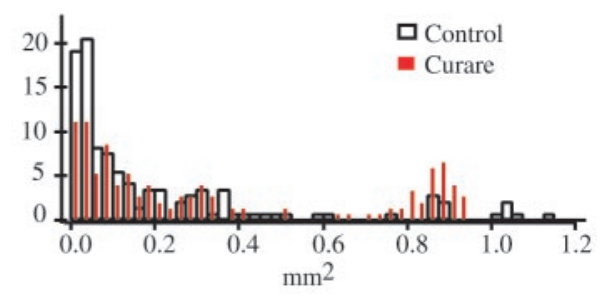

Figure 3. $\beta 2-/-$ mice have altered retinal waves. $A$, Retinal waves of $\mathrm{P} 0 \beta 2-/-$ mice. Same configuration as Figure $2 A$. $B$, Normalized distribution of domain sizes for P0 $\beta 2-/-$ mice in control ACSF (open bars) and in $\mathrm{D}$-tubocurarine (red lines). Bin size is $0.025 \mathrm{~mm}^{2} . n=115$ waves in control solutions; $n=153$ in D-tubocurarine, three retinas, three mice. $C$, Effects of nAChR antagonists $[2 \mu \mathrm{M}$ dihydrobetaerthroidine $(D B E)$ or $100 \mu \mathrm{M}$ D-tubocurarine $(C U R)]$ and non-NMDA ionotropic glutamate receptor antagonists [25 $\mu \mathrm{M} \quad 6,7$ dinitroquinoxaline-2,3-dione $(D N Q X)$ or $50 \mu \mathrm{M}$ 6-cyano7-nitroquinoxaline-2,3-dione $(C N Q X)]$ on $\Delta \mathrm{F} / \mathrm{F}$ averaged over $200 \mu \mathrm{m}^{2}$ regions of retinas from P5-P14 normal and P8-P11 $\beta 2-/-$ mice.

eration of larger waves requires $\mathrm{nAChR}$-mediated synaptic transmission not involving either $\alpha 3$ or $\alpha 7$ subunit-containing nAChRs. In contrast, the mechanism responsible for the smaller regions of simultaneous $\left[\mathrm{Ca}^{2+}\right]_{\mathrm{i}}$ increases is neither $\mathrm{nAChR}$ nor $\mathrm{GABA}_{\mathrm{A}}$ receptor-mediated.

To determine whether these compensatory mechanisms are novel or are the extension of a prenatal phenotype, we studied the properties of waves in normal embryonic mice. The earliest age at which we could record reliably spontaneous increases in $\left[\mathrm{Ca}^{2+}\right]_{i}$ using fluorescence imaging of fura-2 was embryonic day 16 (E16) or E17. Similar to the postnatal $\alpha 3-/-$ retinas, embryonic retinas exhibited two kinds of spontaneous correlated activity: larger propagating waves that were more sensitive to curare (events covering $>0.075 \mathrm{~mm}^{2}$ ) and small regions (covering $<0.075 \mathrm{~mm}^{2}$ ) that underwent correlated increases in $\left[\mathrm{Ca}^{2+}\right]_{\mathrm{i}}$ and were insensitive to nAChR antagonists (Fig. $2 A$, third column). There was a lower percentage of larger waves in the E17 compared with $\alpha 3-/-$ retina (14 vs 33\% E17 normal vs P0-P5 $\alpha 3-/-$ mice; Fig. $2 B$ ), and these larger waves were more sensitive to curare than the small waves (4 of 93 events in curare covered an area $>0.075 \mathrm{~mm}^{2}$ vs 19 of 139 events in control). Waves seen in E17 retinas were similar to those of $\alpha 3-/-$ retinas in that they did not always respect the refractory boundaries defined by previous waves. At E17, however, a given local retinal area participated in more spontaneous events than were observed in postnatal $\alpha 3-/-$ retinas. This increase is attributable in part to a reduction in the wave initiation interval (Table $1)$. These results suggest that retinal waves seen in $\alpha 3-/-$ mice may be mediated, at least in part, by an extension of the embryonic activity-generating mechanism. These experiments do not address whether the presence of the $\alpha 3$ subunit in normal mice acts to suppress the initiation of these small, nonpropagating events or whether the $\alpha 3$ subunit mediates all propagating events.

\section{$\beta 2-/-$ mice do not have nAChR-mediated retinal waves}

Unlike the $\alpha 3-/-$ mice, mice lacking the $\beta 2$ subunit or $\beta 2$ and $\beta 4$ subunits of nAChRs exhibited no correlated spontaneous activity between $\mathrm{P} 1$ and $\mathrm{P} 8$, as assessed by fluorescence imaging. We found this to be the case for $\beta 2-/-\beta 4+/+(n=8), \beta 2-/-\beta 4+/-(n=$ $12)$, and $\beta 2-/-\beta 4-/-$ mice $(n=7)$, indicating that the $\beta 2$, not the $\beta 4$ subunit, is critical in establishing this phenotype.

We found that lack of nAChR-mediated waves between P1 and P8 significantly altered the development of the circuits that mediate waves at other ages. We compared the properties of waves in P0 and P8-P12 $\beta 2-/-$ mice with those measured in control retinas as described above. Waves recorded in P0 $\beta 2-/-$ mice are signifi- cantly different from those in normal postnatal mice (Fig. $3 A ; n=$ 7 mice; compared with Fig. $2 A$, first column). First, P0 $\beta 2-/-$ retinas exhibited both small regions with simultaneous increases in $\left[\mathrm{Ca}^{2+}\right]_{\mathrm{i}}$ and propagating waves that traversed larger regions of the retina. Second, a large percentage of waves propagated across the entire imaged area $\left(>1 \mathrm{~mm}^{2} ; n=3 \beta 2-/-\beta 4-/-\right.$ mice; $n=2$ $\beta 2-/-\beta 4+/-$ mice; $n=3 \beta 2-/-\beta 4+/+$ mice; Fig. $3 B)$, which is rarely seen in control animals (Fig. $2 B$ ). Third, neither the coactive regions nor the propagating waves were inhibited by curare $(100 \mu \mathrm{M}$; $n=7$ experiments, six mice; Fig. $3 A$ ). Fourth, waves recorded in $\mathrm{P} 0$ $\beta 2-/-$ mice did not respect refractory boundaries (Fig. $3 A$ ). Other spatiotemporal properties of these waves are listed in Table 1.

Mouse retinas, like ferret (Wong, 1999) and rabbit (Zhou and Zhao, 2000) retinas, make a developmentally regulated switch from a nAChR-mediated wave-generating circuit to one mediated by ionotropic glutamate receptors (Fig. $3 C$ ). In normal animals, between P5 and P11, waves are blocked by nAChR antagonists ( $2 \mu \mathrm{M}$ dihydrobetaerthroidine or $100 \mu \mathrm{M}$ curare; $n=28$ in 11 mice). During this period, the amplitudes of the $\Delta \mathrm{F} / \mathrm{Fs}$ associated with waves are attenuated but not blocked by non-NMDA glutamate receptor antagonists $(25 \mu \mathrm{M}$ DNQX or $50 \mu \mathrm{M} C N Q X ; \Delta \mathrm{F} / \mathrm{F}=$ $50.4 \pm 17.0 \%$ of control; $n=26$ in 13 mice). Between P12 and P14, however, we observed that waves are completely blocked by the non-NMDA receptor antagonists $(n=5$ in 4 mice). Waves at these older ages are weakly modulated by $\mathrm{nAChR}$ antagonists $(\Delta \mathrm{F} / \mathrm{F}=$ $64.8 \pm 12.6 \%$ of control; $n=2$ in two mice). These results indicate that the developmental switch in wave-generating circuitry occurs at approximately P11 in normal animals.

In $\beta 2-/-$ mice, waves are absent between P1 and P8. When they emerge at P8, waves are mediated by an ionotropic glutamate receptor-based circuit (Fig. $3 C$ ). These waves are always blocked by non-NMDA receptor antagonists $(n=8$, three $\beta 2-/-$ mice $)$ but not by $\mathrm{nAChR}$ antagonists $(\Delta \mathrm{F} / \mathrm{F}=90.6 \pm 13.5 \%$ of control; $n=$ 8 , three $\beta 2-/-$ mice $)$. In accordance with these imaging results, whole-cell current-clamp recordings in 14 of 14 RGCs from normal mice $(n=5$ mice, P7-P13) and in 28 of 31 RGCs from $\beta 2-/-$ mice ( $n=10$ mice, P7-P13) showed rhythmic spontaneous depolarizations (data not shown). The periodicity of these depolarizations was not significantly different (intervals of $74.08 \pm 10.90 \mathrm{sec}$ for normal and $70.98 \pm 7.08 \mathrm{sec}$ for $\beta 2-/-$ mice; $p=0.81$ ), and the depolarizations were blocked by bath application of $25 \mu \mathrm{M}$ DNQX ( $n=8$ cells in 5 mice for normal mice; $n=13$ cells in seven $\beta 2-/-$ mice). These observations on the pharmacological profile of waves in $\beta 2-/-$ mice suggest that the absence of an nAChR-based circuit 


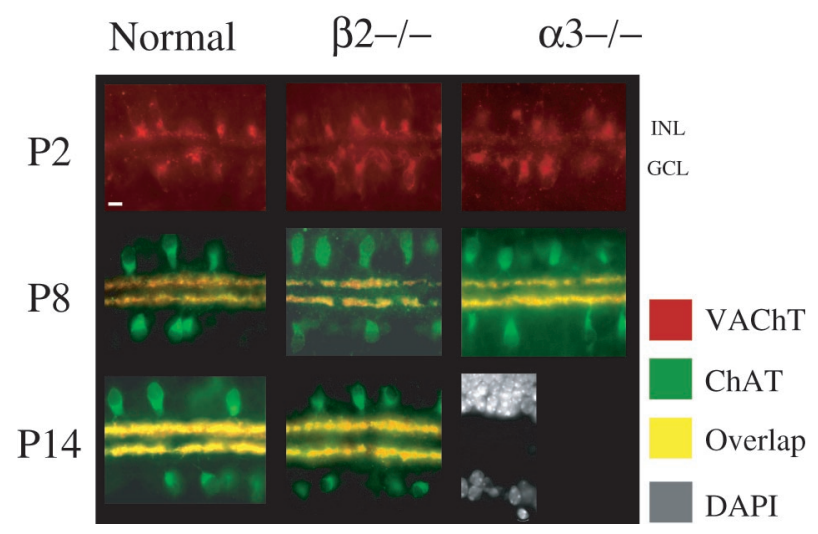

Figure 4. Stratification of cholinergic neurons from P2 to P14 is normal in $\beta 2-/-$ and $\alpha 3-/-$ mice. Transverse sections of mouse retinas immunostained for ChAT and VAChT are shown. P2 retinas are only stained for VAChT. Bottom right panel, DAPI-labeled neuronal somas in the INL (top) and GCL (bottom). Scale bar, $10 \mu \mathrm{m}$.

allows for the precocious appearance of glutamate receptormediated waves. We did not study this transition in $\alpha 3-/-$ mice, because most of these mice die by P8 (Xu et al., 1999a).

\section{Altered retinal waves do not alter the stratification of cholinergic amacrine cells}

Because $\beta 2-/-$ mice lacked retinal waves and $\alpha 3-/-$ mice had altered retinal waves during the first postnatal week of development, we studied them to determine whether nAChR-mediated activity influences the anatomical features of the inner retina. We first examined the distribution of retinal cholinergic neurons, a subpopulation of amacrine cells called starburst amacrine cells (Vaney, 1984; Masland and Tauchi, 1986). The highly stereotyped distribution of these cells is well characterized in a number of mammalian species (Voigt, 1986; Vardi et al., 1989; Famiglietti, 1991). Their processes stratify very early in development into either a single OFF or ON sublamina (Feller et al., 1996; West Greenlee et al., 1998). To determine whether activation of nAChRs containing $\alpha 3, \beta 2$, or $\beta 4$ subunits was required for the distribution and stratification of starburst amacrine cells, we used two antibodies directed against markers of cholinergic neurons, anti-ChAT and anti-VAChT.

At all ages examined, ChAT was localized to a subset of amacrine cell somas located both in the inner nuclear layer (INL) and displaced into the ganglion cell layer (GCL), and it was colocalized with VAChT in the amacrine cell processes in the ON and OFF sublaminae (Fig. 4). Except at the earliest ages examined, VAChT was not found in amacrine cell somas. Both ChAT and VAChT expression were evident at $\mathrm{P} 2$, although ChAT expression was often quite low (data not shown). At all developmental ages, there was no difference in the distribution and stratification of ChAT- or VAChT-immunopositive cells among normal, $\beta 2-/-$, and $\alpha 3-/-$ retinas ( $n=3$ retinas for each phenotype and age). Similar results were found for $\mathrm{P} 2$ and $\mathrm{P} 8 \beta 2-/-\beta 4-/-$ retinas $(n=3$ mice each age; data not shown). These findings suggest that neither the subunit composition of retinal nAChRs nor the existence of nAChR-mediated retinal waves influences the development or distribution of cholinergic processes.

\section{Waves mediated by $\mathrm{ACh}$ have a limited role in the stratification of RGC dendrites}

The adult IPL is organized into five distinct strata where different cell types, defined by a combination of immunohistochemical markers and physiological response properties, make their synaptic connections in spatially segregated bands (Wassle and Boycott, 1991; Kolb, 1997). The five strata are grouped into two sublaminae: the two strata closest to the INL constitute the OFF sublamina and contain processes of cells responding to decreases in illumination; the three strata closest to the RGC layer constitute the ON sub- lamina and contain the processes of cells responding to increases in illumination (Kolb, 1997). Previous work indicates that RGC dendritic stratification depends on glutamate-mediated afferent activity from bipolar cells (Bodnarenko and Chalupa, 1993; Chapman et al., 1996). However, as seen in Figure 4, during the developmental period $(\mathrm{P} 0-\mathrm{P} 8)$ when retinal waves are mediated normally by activation of nAChRs, cholinergic neurons in $\beta 2-/-$ and $\alpha 3-/-$ retinas were already stratified in distinct layers within the $\mathrm{ON}$ and OFF sublaminae of the IPL. Because distinct classes of RGCs co-stratify with cholinergic neurons (Vardi et al., 1989; Famiglietti, 1992), we asked whether RGC dendritic stratification was altered by the absence of normal nAChR-mediated retinal activity. We therefore compared the developmental time course of RGC dendritic stratification in wild-type and $\beta 2-/-$ mice.

To assay stratification, we applied crystals of the lipophilic fluorescent tracer molecule DiI to the optic nerve stump of paraformaldehyde-fixed eyes from both normal and transgenic animals (Fig. 5A1). This technique permits bulk loading by passive diffusion of most or all of the RGCs in the retina (Bodnarenko et al., 1995). RGC dendritic processes were then reconstructed from fluorescence images of whole-mount retinas taken on a confocal microscope and later analyzed in cross section to determine the number of dendritic strata and the thickness of the IPL (Fig. 5A2). In each retina, confocal scans were conducted at four to eight locations across the mid- to mid-peripheral retina.

At $\mathrm{P} 2$, the inner retina in both normal and $\beta 2-/-$ mice was quite immature, with a thick GCL (two or three cell bodies thick), a thin IPL, and no apparent dendritic stratifications (Fig. 5A2, top). By P8, at the end of the period with no wave activity in $\beta 2-/-$ retinas, nearly all regions studied in both normal and $\beta 2-/-$ mice had segregated into at least two distinct bands, the presumptive ON and OFF sublaminae (Fig. 5A2, middle). Thus the lack of $\mathrm{nAChR}$ activation did not prevent this first stage of gross segregation. There was a small but insignificant difference, however, in the extent of dendritic stratification between normal and transgenic mice. The number of distinct layers observed in the IPL ranged from one to four strata in both normal and $\beta 2-/-$ retinas (Fig. $5 A 3)$. These variations in the number of strata did not correlate with different locations in the retina. In P8 wild-type mice the median number of strata observed was three $(n=19$ measurements from three normal mice; Fig. 5A3). In P8 $\beta 2-/-$ retinas, the median number of strata was two $(n=17$ from four $\beta 2-/-$ mice $)$, but this difference was not statistically significant (Mann-Whitney test, $p=0.21)$. The retinas of P $\beta 2-/-\beta 4-/-$ and $\alpha 3-/-$ mice had significantly narrower IPLs, perhaps because of the reduced overall size of the eye (Xu et al., 1999a,b), and RGC dendrites were not stratified or were only weakly stratified into two distinct sublaminae (data not shown, 8 measurements, two $\beta 2-/-\beta 4-/-$ mice; 20 measurements, four $\alpha 3-/-$ mice). These were not included in the population analysis. Dendritic stratification of $\beta 2-/-$ $\beta 4+/-$ mice was not measured.

Between P8 and eye opening (P14), when retinal waves are mediated by ionotropic glutamate receptor-mediated transmission, the IPL in both normal and $\beta 2-/-$ mice approximately doubled in size, and RGC dendrites segregated into four or five distinguishable strata (Fig. 5A2, bottom). These findings are consistent with previous observations that this refinement is mediated by glutamatergic neurotransmission (Bodnarenko and Chalupa, 1993), because this transmission persists in $\beta 2-/-$ mice between P8 and P14.

DiI labeling of RGCs also allowed us to ensure that there was no change in the density of RGCs between normal and $\beta 2-/-$ retinas. RGCs undergo a tremendous amount of apoptotic cell death during the first few postnatal days in mice; approximately half of all RGCs die during this period (Young, 1984). Recent experiments indicate that RGC survival may require spontaneous retinal activity (Shen et al., 1999). By counting the DiI-labeled RGCs in the confocal section containing the ganglion cell layer (Fig. 5A1, left frame), we determined that at $\mathrm{P} 8$, after the period of cell death, there was no significant difference in the density of cells between normal and $\beta 2-/-$ mice $\left(1266 \pm 433\right.$ cells $/ \mathrm{mm}^{2} ; n=23$, four 
A1

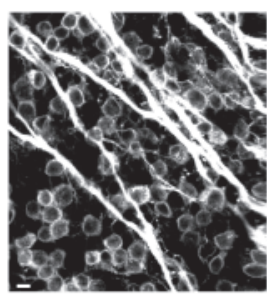

RGCs and axons

(GCL)

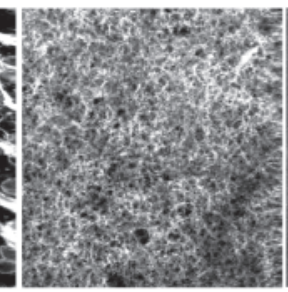

RGC dendrites

(IPL)

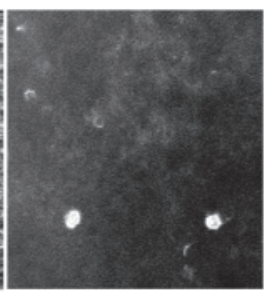

Displaced RGCs (INL)

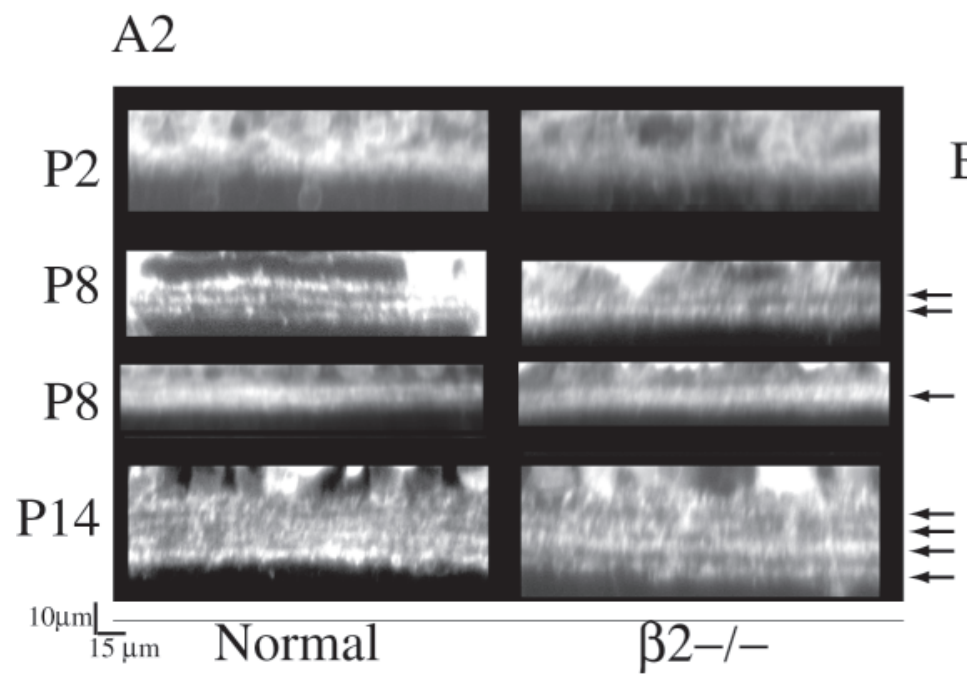

B1
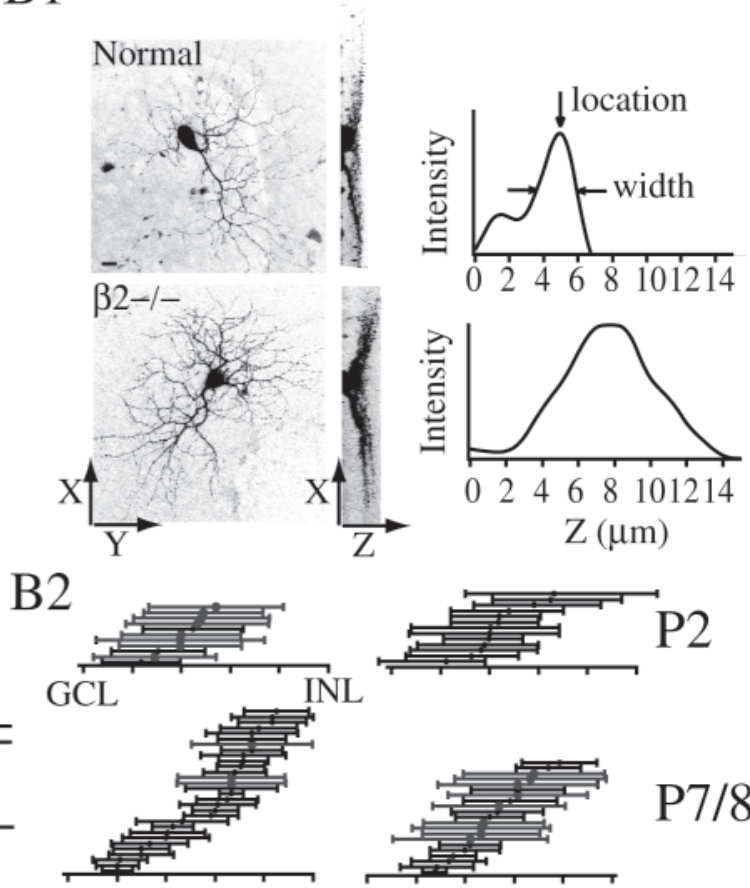

$\mathrm{P} 7 / 8$

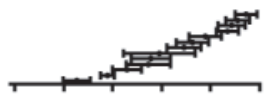

Normal

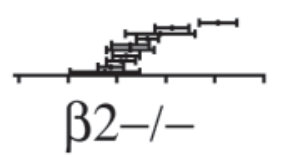

P14

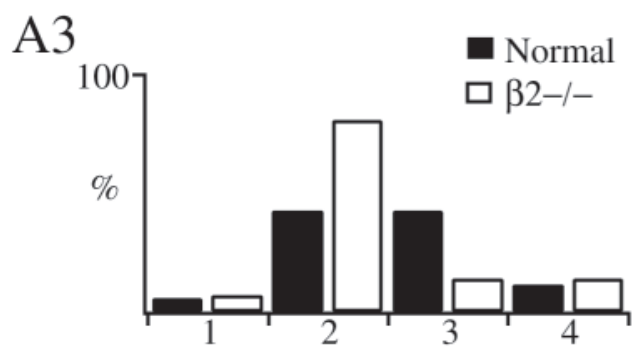

\# of strata at P8
B3

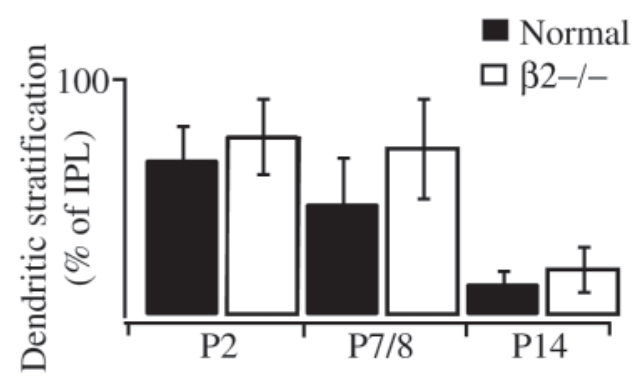

Figure 5. RGCs from $\beta 2-/-$ mice show slowed segregation into the adult strata pattern. $A 1$, Confocal sections of DiI-labeled RGCs at different focal depths (GCL, IPL, and INL). Scale bar, $10 \mu \mathrm{m}$. A2, Cross-sectional projection of DiI reconstructions averaged over $250 \mu \mathrm{m}$ of retina. Arrows show individual layers. Scale bar, $15 \mu \mathrm{m}$. At P8, examples of retinas that contained a single stratum are also shown. $A 3$, Distribution of the number of strata in retinas from P8 normal and $\beta 2-/-$ mice. B1, Left, XY projection of 3-D-reconstructed, Lucifer yellow-filled RGCs from P8 normal and $\beta 2-/-$ mice. Scale bar, $10 \mu \mathrm{m}$. Middle, $x-z$ projection of same cells. Right, Pixel intensity profiles of $x-z$ projection averaged over the $y$-axis, normalized to maximum pixel intensity. The region containing the cell body has been excluded. B2, Lucifer yellow-filled RGCs in P2, P7-P8, and P14 retinas from normal and $\beta 2-/-$ mice. Cells are arranged by relative location in IPL, and error bars indicate the width of dendritic stratification (see location and width arrows in B1). B3, Widths of dendritic stratification for P2, P7-P8, and P14 normal and $\beta 2-/-$ mice. Stratification widths are normalized to the total width of the IPL. Error bars indicate SD.

normal mice; $1300 \pm 310$ cells $/ \mathrm{mm}^{2} ; n=14$, five $\beta 2-/-$ mice; $p=0.79)$. We conclude that the absence of waves from P1 to P7 did not alter the overall amount of cell death. However, the spontaneous correlated $\left[\mathrm{Ca}^{2+}\right]_{\mathrm{i}}$ increases mediated by some compensatory mechanism seen in $\mathrm{P} 0 \beta 2-/-$ mice (Fig. $3 A$ ) may be sufficient to initiate an activity-dependent survival process (Shen et al., 1999).

Although application of DiI to the optic nerve allowed us to visualize the dendritic stratification of RGCs averaged over the entire population of RGC types, this technique might have overshadowed the effects of wave-induced activity on individual cell types. It is possible that nAChR transmission mediates the stratification of only a subset of RGCs, because only a subset of RGCs is known to colocalize with the ChAT-positive bands shown in Figure $4 A$ (Vardi et al., 1989; Famiglietti, 1992). Therefore, we quantified the stratification of individual RGCs in both wild-type and $\beta 2-/-$ mice.

Individual RGCs were filled using a whole-cell recording pipette containing internal solution and the fluorescent dye Lucifer yellow $(0.5 \%)$. Fluorescence images of filled RGCs acquired with either a deconvolution microscope or a confocal microscope enabled us to measure the width of dendritic stratification and its location within the IPL (Fig. 5B1). To measure the IPL width, all somas were stained by bath application of DAPI; the width of the IPL was taken as the distance between DAPI-labeled cell nuclei in the GCL 
Normal

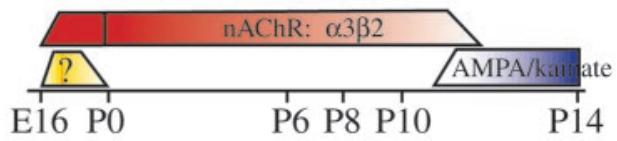

$\beta 2-1-$

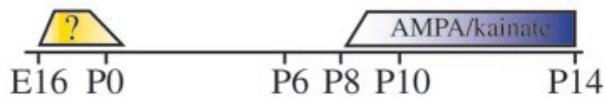

$\alpha 3-1-$

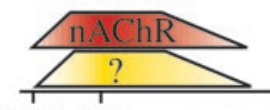

E16 P0

P14
Figure 6. Summary of development of the synaptic circuitry that mediates waves in normal, $\beta 2-/-$, and $\alpha 3-/-$ retinas. Each color corresponds to a different wave-generating circuit: yellow corresponds to non-nAChR circuitry that mediates the nonpropagating events in embryonic normal and postnatal $\alpha 3-/-$ mice and the propagating event in P0 $\beta 2-/-$ mice; red corresponds to circuits that require activation of nAChRs; and blue corresponds to circuits that require activation of ionotropic glutamate receptors. The wave-generating circuitry in $\alpha 3-/-$ retinas was not studied in the second postnatal week because of the premature death of the transgenic mice.

and INL. Figure $5 B 2$ contains the measurements of individual RGC stratification widths organized by location within the IPL.

At P2, consistent with the DiI measurements, we found that dendrites of individual RGCs from wild-type ( $n=11$ cells, two mice) or $\beta 2-/-$ mice $(n=13$ cells, two mice) ramified throughout the IPL (Fig. 5B3). By P7-P8, RGC dendrites in control retinas were more narrowly stratified than those in $\beta 2-/-$ retinas $(47 \pm$ $20 \%$ of IPL; $n=28$ cells, five normal mice; compared with $70 \pm$ $21 \%$ of IPL; $n=34$ cells, six $\beta 2-/-$ mice; $p<0.001$; Fig. 5B2,B3). In addition, RGC dendrites in control retinas showed some restriction to the ON or OFF sublaminae, whereas those in $\beta 2-/-$ retinas did not (Fig. 5B2). By P14, in both wild-type $(n=13$ cells, two mice $)$ and $\beta 2-/-(n=10$ cells, three mice $)$ mice, nearly all the RGCs were narrowly stratified (Fig. 5B3). Thus, the observation that the strata in $\beta 2-/-$ retinas are delayed in formation compared with normal mice at P7-P8 (Fig. 5A) could be attributable to the delayed segregation of a subset of RGCs into the appropriate strata.

\section{DISCUSSION}

\section{Altered activity patterns can change the development of functional circuits that mediate retinal waves}

In mouse retina, the synaptic circuitry responsible for the spontaneous generation of correlated $\left[\mathrm{Ca}^{2+}\right]_{i}$ increases in the GCL evolves through three stages: E16-P0, P0-P11, and P11-P14 (Fig. 6 ). Normal embryonic retinas support spontaneous activity that comprises simultaneous increases of $\left[\mathrm{Ca}^{2+}\right]_{i}$ in small clusters of cells mediated by a non-nAChR circuit and activity that propagates over substantially larger regions mediated by the activation of nAChRs. During the first postnatal week, the normal retinal circuitry matures so that there are no longer small coactive domains but only propagating activity that is dependent on cholinergic transmission mediated by $\alpha 3$ and $\beta 2$ subunit-containing nAChRs. We have demonstrated that mice lacking the $\alpha 3$ subunit continue to support nAChR-mediated propagating retinal activity for at least 5 postnatal days. In contrast, $\beta 2-/-$ retinas cannot support activity during the first postnatal week, indicating that the $\beta 2$ and not the $\alpha 3$ subunit is required to form postsynaptic nAChRs that mediate waves.

During the second postnatal week, propagating activity is mediated, at least in part, by ionotropic glutamate receptors. Is cholinergic activity required for the normal development of the glutamatergic wave-generating circuit? We observed that $\beta 2-/-$ mice do make the switch to ionotropic glutamate receptor-mediated waves; however, they make this transition 3-4 d earlier than normal mice (Fig. $3 C$ ). Note that although ionotropic glutamate receptor antagonists do not block fluorescence changes of the overall cell popu- lation in control P8-P11 retinas, they do block the rhythmic depolarizations recorded by whole-cell current clamp in individual RGCs. This apparent discrepancy might be attributable to the fact that recordings are from primarily $\alpha$-type RGCs, and this particular subtype of RGC may be more sensitive to glutamatic modulation a few days earlier than the network as a whole.

It is important to emphasize that even before the transition to ionotropic, glutamate receptor-mediated waves occurs in normal mice, the amplitude of fluorescence changes associated with retinal waves is reduced in the presence of ionotropic glutamate receptor antagonists (Fig. 3C). Glutamate secreted from migrating neurons or from transient photoreceptor synapses in the IPL may modulate spontaneous firing before bipolar cell synapses form (see Wong et al., 2000, Discussion). Thus, upregulation of this source of glutamate or possibly a premature establishment of bipolar cell synapses in the IPL may lead to the precocious onset of the glutamatergic circuit induced by the lack of nAChR-mediated waves.

Our studies reveal a novel non-nAChR-based mechanism for wave generation. The small, coactive regions seen in embryonic normal and postnatal $\alpha 3-/-$ mice (Fig. $2 A$ ), as well as the propagating activity observed in $\mathrm{P} 0 \beta 2-/-$ mice (Fig. $3 A$ ), persist in the presence of general nAChR antagonists. This activity may be mediated by a combination of gap junctions and chemical synaptic transmission, in some cases involving metabotropic receptormediated signaling (Catsicas et al., 1998; Wong et al., 1998; Sernagor and Grzywacz, 1999; Zhou and Zhao, 2000). Similar mechanisms have been proposed to account for spontaneous activity in a variety of circuits throughout the developing CNS (Yuste, 1997), including the hippocampus (Leinekugel et al., 1997; Garaschuk et al., 1998) and neocortex (Yuste et al., 1992; Owens and Kriegstein, 1998; Schwartz et al., 1998; Peinado, 2000). It is unlikely that activity would be propagated via diffusion of extracellular excitatory substances, such as potassium (Burgi and Grzywacz, 1994; Sernagor and Grzywacz, 1999), because the regions of activation are quite limited (Copenhagen, 1996).

The observation that different circuits can generate rhythmic depolarizations and propagating activity patterns in the same neural circuit at different stages of development is not unique to the retina. The developing chick spinal cord supports spontaneous correlated activity among synaptically connected interneurons and motoneurons that also undergoes a developmental change in circuitry. The primary neurotransmitter that drives activity switches from acetylcholine at E5 (Milner and Landmesser, 1999) to glutamate at E10 (O'Donovan and Chub, 1997). Remarkably, even at a single developmental stage, spinal cord circuits can produce appropriate rhythmic activity via more than one mechanism. Activity suppressed by nicotinic (at E5) or ionotropic glutamatergic (at E10) receptor blockade is restored after some delay, now mediated by GABAergic and glycinergic transmission (Chub and O'Donovan, 1998; Milner and Landmesser, 1999). Thus both the retina and spinal cord can alter their normal developmental program to compensate for the lack of activity, perhaps through a homeostatic regulation of the firing properties of the network (O'Donovan and Chub, 1997; Feller, 1999).

\section{nAChR-mediated waves play a limited role in the segregation of RGC dendrites into the adult pattern of strata}

Cholinergic neurons are present in the mouse retina, and the patterning of their projections defines the $\mathrm{ON}$ and OFF sublaminae very early in retinal development (Fig. 4). This agrees with studies in other species: cat (Dann, 1989; Mitrofanis et al., 1989), chicken (Spira et al., 1987; Layer et al., 1997), marsupials (West Greenlee et al., 1998), rabbit (Wong and Collin, 1989), and ferret (Feller et al., 1996). In mouse, we found that RGC dendrites are localized to the ON and OFF sublaminae by P8 and further segregate into the five strata that characterize the adult retina by P14 (Fig. 5). Again, this finding is consistent with the early stratification of RGC dendrites seen in ferret (Bodnarenko et al., 1999) and cat (Bodnarenko et al., 1995). Although the maintenance of RGC 
dendritic segregation into ON and OFF sublaminae is known to be activity-dependent (Bodnarenko and Chalupa, 1993; Wingate and Thompson, 1994; Bodnarenko et al., 1995), the absence of spontaneous, correlated activity in the $\beta 2-/-$ retinas did not prevent initial segregation of RGC dendrites into the ON and OFF sublaminae. It did delay, however, their further refinement into the adult pattern of strata.

The ON-OFF segregation of ganglion cell dendrites is thought to be directed by the activity of glutamatergic bipolar cells whose axon terminals are restricted to either the ON or OFF sublaminae of the IPL (Bodnarenko and Chalupa, 1993). In the developing cat retina, inhibition of glutamatergic synaptic transmission from ON cone bipolar and rod bipolar cells with intraocular injections of the metabotropic glutamate receptor agonist 2-amino-4-phosphonobutyrate prevents the initially diffuse population of RGC dendrites from segregating into $\mathrm{ON}$ and OFF sublaminae (Bodnarenko and Chalupa, 1993; Chapman, 2000). This failure to segregate is permanent, and functional studies of the mature visual system reveal many RGCs exhibiting both ON and OFF responses to light (Bisti et al., 1998).

Our findings indicate, however, that the initial segregation into ON and OFF sublaminae may occur before bipolar cells have made functional synapses in the IPL. In the rat retina, bipolar cell terminals, identified by recoverin immunolabeling, segregated into the ON and OFF sublaminae of the IPL by P8 (Gunhan-Agar et al., 2000); in the ferret retina, this process begins at P10 and is complete by P15 (Miller et al., 1999). In ferret, the appearance of bipolar cell axon terminals in the IPL coincides with the transition of spontaneous, correlated activity from an nAChR- to a glutamate receptor-mediated process (Wong et al., 2000). Assuming that in mouse retina the developmental switch from nAChR-mediated to ionotropic glutamate receptor-mediated activity coincides with the maturation of glutamatergic bipolar cell processes, these processes should appear at approximately P11. Because the initial segregation into $\mathrm{ON}$ and OFF sublaminae in normal and $\beta 2-/-$ mice occurs by P8, it must occur independently of both nAChRmediated and bipolar cell-mediated activity. This is consistent with the recent finding that mice deficient in the predominant bipolar cell metabotropic glutamate receptor mGluR6 have normal segregation of RGC dendrites (Tagawa et al., 1999).

What then drives the initial RGC dendritic segregation? One possibility is that activation of ionotropic glutamate receptors during the first postnatal week (Fig. 3C) is necessary for RGC dendrites to migrate into the appropriate sublaminae (Wong and Wong, 2000). However, because the cholinergic circuitry is organized so early in development, it seems likely that it plays some role in organizing synaptic connections in the inner retina. The earliest markers of ON and OFF sublaminae found in the chick IPL are the cholinergic synapse-associated enzymes butrylcholinesterase and acetylcholinesterase. These molecules appear very early in embryonic development when the IPL first forms (Layer et al., 1997) and may serve as signals for the initial RGC dendritic stratification. In turtle retina, choline acetyltransferase also precedes the formation of synapses (Nguyen et al., 2000). The idea that molecules can define sublaminae in the IPL could also explain bipolar cell stratification in the absence of postsynaptic targets (Gunhan-Agar et al., 2000). If cholinergic synapses are the scaffolding around which the $\mathrm{ON}$ and OFF sublaminae are built, the finding that $\mathrm{ON}-\mathrm{OFF}$ segregation occurs in mice lacking either $\alpha 3$ or $\beta 2 \mathrm{nAChR}$ subunits suggests that lamination is guided either by cholinergic transmission mediated by muscarinic AChRs (Zhou and Zhao, 2000) by non- $\alpha 3,-\beta 2$, or $-\beta 4 \mathrm{nAChRs}$ or by an activity-independent mechanism.

We found that cholinergic transmission did play a role in the refinement of RGC dendritic arbors into the five distinct strata that define the adult IPL. The delay of this refinement in P8 $\beta 2-/-$ retinas may result directly from a lack of cholinergic inputs onto RGC dendrites or indirectly from a reduced cholinergic drive onto glutamatergic bipolar cells (Hamassaki-Britto et al., 1994). The delay we observed in the stratification of RGCs in P8 $\beta 2-/-$ mice was eliminated by P14, indicating that spontaneous activity mediated by ionotropic glutamate receptors is sufficient to drive the stratification of RGC dendrites into their adult pattern.

In summary, we have characterized the changes in the spontaneous activity and anatomy of retinas from mice lacking $\alpha 3, \beta 2$, or $\beta 2$ and $\beta 4$ subunits of the nAChR. Together, our findings indicate that $\mathrm{nAChR}$-mediated spontaneous activity plays a distinct role in the normal developmental progression of functional circuits that mediate waves and a more limited role in the formation of the $\mathrm{ON}-\mathrm{OFF}$ anatomical circuits in the inner retina.

\section{REFERENCES}

Aizenman E, Loring RH, Lipton SA (1990) Blockade of nicotinic responses in rat retinal ganglion cells by neuronal bungarotoxin. Brain Res 517:209-214.

Baldridge WH (1996) Optical recordings of the effects of cholinergic ligands on neurons in the ganglion cell layer of mammalian retina. J Neurosci 16:5060-5072.

Bisti S, Gargini C, Chalupa LM (1998) Blockade of glutamate-mediated activity in the developing retina perturbs the functional segregation of ON and OFF pathways. J Neurosci 18:5019-5025.

Bodnarenko SR, Chalupa LM (1993) Stratification of ON and OFF ganglion cell dendrites depends on glutamate-mediated afferent activity in the developing retina. Nature 364:144-146.

Bodnarenko SR, Jeyarasasingam G, Chalupa LM (1995) Development and regulation of dendritic stratification in retinal ganglion cells by glutamate-mediated afferent activity. J Neurosci 15:7037-7045.

Bodnarenko SR, Yeung G, Thomas L, McCarthy M (1999) The development of retinal ganglion cell dendritic stratification in ferrets. NeuroReport 10:2955-2959.

Burgi PY, Grzywacz NM (1994) Model for the pharmacological basis of spontaneous synchronous activity in developing retinas. J Neurosci 14:7426-7439.

Campbell G, Ramoa AS, Stryker MP, Shatz CJ (1997) Dendritic development of retinal ganglion cells after prenatal intracranial infusion of tetrodotoxin. Vis Neurosci 14:779-788.

Cartier GE, Yoshikami D, Gray WR, Luo S, Olivera BM, McIntosh JM (1996) A new alpha-conotoxin which targets alpha3beta2 nicotinic acetylcholine receptors. J Biol Chem 271:7522-7528.

Catsicas M, Bonness V, Becker D, Mobbs P (1998) Spontaneous Ca ${ }^{2+}$ transients and their transmission in the developing chick retina. Curr Biol 8:283-286.

Chapman B (2000) Necessity for afferent activity to maintain eye-specific segregation in ferret lateral geniculate nucleus. Science 287:2479-2482.

Chapman B, Godecke I (2000) Cortical cell orientation selectivity fails to develop in the absence of ON-center retinal ganglion cell activity. J Neurosci 20:1922-1930.

Chapman B, Stryker MP, Bonhoeffer T (1996) Development of orientation preference maps in ferret primary visual cortex. J Neurosci 16:6443-6453.

Chub N, O’Donovan MJ (1998) Blockade and recovery of spontaneous rhythmic activity after application of neurotransmitter antagonists to spinal networks of the chick embryo. J Neurosci 18:294-306.

Cook PM, Prusky G, Ramoa AS (1999) The role of spontaneous retinal activity before eye opening in the maturation of form and function in the retinogeniculate pathway of the ferret. Vis Neurosci 16:491-501.

Copenhagen DR (1996) Retinal development: on the crest of an exciting wave. Curr Biol 6:1368-1370.

Crowley JC, Katz LC (1999) Development of ocular dominance columns in the absence of retinal input. Nat Neurosci 2:1125-1130.

Dann JF (1989) Cholinergic amacrine cells in the developing cat retina. J Comp Neurol 289:143-155.

Famiglietti EV (1991) Synaptic organization of starburst amacrine cells in rabbit retina: analysis of serial thin sections by electron microscopy and graphic reconstruction. J Comp Neurol 309:40-70.

Famiglietti EV (1992) Dendritic co-stratification of ON and ON-OFF directionally selective ganglion cells with starburst amacrine cells in rabbit retina. J Comp Neurol 324:322-335.

Feller MB (1999) Spontaneous correlated activity in developing neural circuits. Neuron 22:653-656.

Feller MB, Wellis DP, Stellwagen D, Werblin FS, Shatz CJ (1996) Requirement for cholinergic synaptic transmission in the propagation of spontaneous retinal waves. Science 272:1182-1187.

Feller MB, Butts DA, Aaron HL, Rokhsar DS, Shatz CJ (1997) Dynamic processes shape spatiotemporal properties of retinal waves. Neuron 19:293-306.

Garaschuk O, Hanse E, Konnerth A (1998) Developmental profile and synaptic origin of early network oscillations in the CA1 region of rat neonatal hippocampus. J Physiol (Lond) 507:219-236.

Gunhan-Agar E, Kahn D, Chalupa LM (2000) Segregation of On and Off bipolar cell axonal arbors in the absence of retinal ganglion cells. J Neurosci 20:306-314.

Hamassaki-Britto DE, Gardino PF, Hokoc JN, Keyser KT, Karten HJ, Lindstrom JM, Britto LR (1994) Differential development of alpha- 
bungarotoxin-sensitive and alpha- bungarotoxin-insensitive nicotinic acetylcholine receptors in the chick retina. J Comp Neurol 347:161-170.

Kolb H (1997) Amacrine cells of the mammalian retina: neurocircuitry and functional roles. Eye 11:904-923.

Lau KC, So KF, Tay D (1992) APV prevents the elimination of transient dendritic spines on a population of retinal ganglion cells. Brain Res 595:171-174.

Layer PG, Berger J, Kinkl N (1997) Cholinesterases precede "ON-OFF" channel dichotomy in the embryonic chick retina before onset of synaptogenesis. Cell Tissue Res 288:407-416.

Leinekugel X, Medina I, Khalilov I, Ben-Ari Y, Khazipov R (1997) $\mathrm{Ca}^{2+}$ oscillations mediated by the synergistic excitatory actions of GABA(A) and NMDA receptors in the neonatal hippocampus. Neuron 18:243-255.

Luo S, Kulak JM, Cartier GE, Jacobsen RB, Yoshikami D, Olivera BM, McIntosh JM (1998) alpha-conotoxin AuIB selectively blocks alpha3 beta4 nicotinic acetylcholine receptors and nicotine-evoked norepinephrine release. J Neurosci 18:8571-8579.

Marubio LM, del Mar Arroyo-Jimenez M, Cordero-Erausquin M, Lena C, Le Novere N, de Kerchove d'Exaerde A, Huchet M, Damaj MI, Changeux JP (1999) Reduced antinociception in mice lacking neuronal nicotinic receptor subunits. Nature 398:805-810.

Masland RH (1977) Maturation of function in the developing rabbit retina. J Comp Neurol 175:275-286.

Masland RH, Tauchi M (1986) The cholinergic amacrine cell. Trends Neurosci 9:218-223.

McGehee DS, Role LW (1995) Physiological diversity of nicotinic acetylcholine receptors expressed by vertebrate neurons. Annu Rev Physiol 57:521-546.

Miller ED, Tran MN, Wong GK, Oakley DM, Wong RO (1999) Morphological differentiation of bipolar cells in the ferret retina (in process citation). Vis Neurosci 16:1133-1144.

Milner LD, Landmesser LT (1999) Cholinergic and GABAergic inputs drive patterned spontaneous motoneuron activity before target contact. J Neurosci 19:3007-3022.

Mitrofanis J, Maslim J, Stone J (1989) Ontogeny of catecholaminergic and cholinergic cell distributions in the cat's retina. J Comp Neurol 289:228-246.

Nguyen LT, De Juan J, Mejia M, Grzywacz NM (2000) Localization of choline acetyltransferase in the developing and adult turtle retinas. J Comp Neurol 420:512-526.

O'Donovan M, Chub N (1997) Population behavior and self-organization in the genesis of spontaneous rhythmic activity by developing spinal networks. Semin Cell Dev Biol 8:21-28.

Owens DF, Kriegstein AR (1998) Patterns of intracellular calcium fluctuation in precursor cells of the neocortical ventricular zone. J Neurosci 18:5374-5388.

Peinado A (2000) Traveling slow waves of neural activity: a novel form of network activity in developing neocortex. J Neurosci 20:RC54.

Penn AA, Riquelme PA, Feller MB, Shatz CJ (1998) Competition in retinogeniculate patterning driven by spontaneous activity. Science 279:2108-2112.

Picciotto MR, Zoli M, Lena C, Bessis A, Lallemand Y, LeNovere N, Vincent P, Pich EM, Brulet P, Changeux JP (1995) Abnormal avoidance learning in mice lacking functional high-affinity nicotine receptor in the brain. Nature 374:65-67.

Ramirez-Latorre J, Yu CR, Qu X, Perin F, Karlin A, Role L (1996) Functional contributions of alpha5 subunit to neuronal acetylcholine receptor channels. Nature 380:347-351.

Role LW, Berg DK (1996) Nicotinic receptors in the development and modulation of CNS synapses. Neuron 16:1077-1085.

Sargent PB (1993) The diversity of neuronal nicotinic acetylcholine receptors. Annu Rev Neurosci 16:403-443.

Schwartz TH, Rabinowitz D, Unni V, Kumar VS, Smetters DK, Tsiola A Yuste R (1998) Networks of coactive neurons in developing layer 1. Neuron 20:541-552.

Sernagor E, Grzywacz NM (1996) Influence of spontaneous activity and visual experience on developing retinal receptive fields. Curr Biol 6:1503-1508.

Sernagor E, Grzywacz NM (1999) Spontaneous activity in developing turtle retinal ganglion cells: pharmacological studies. J Neurosci 19:3874-3887.

Sernagor E, Eglen SJ, O'Donovan MJ (2000) Differential effects of acetylcholine and glutamate blockade on the spatiotemporal dynamics of retinal waves. J Neurosci 20:RC56.
Shatz CJ, Stryker MP (1988) Prenatal tetrodotoxin infusion blocks segregation of retinogeniculate afferents. Science 242:87-89.

Shen S, Wiemelt AP, McMorris FA, Barres BA (1999) Retinal ganglion cells lose trophic responsiveness after axotomy. Neuron 23:285-295.

Spira AW, Millar TJ, Ishimoto I, Epstein ML, Johnson CD, Dahl JL, Morgan IG (1987) Localization of choline acetyltransferase-like immunoreactivity in the embryonic chick retina. J Comp Neurol 260:526-538.

Tagawa Y, Sawai H, Ueda Y, Tauchi M, Nakanishi S (1999) Immunohistological studies of metabotropic glutamate receptor subtype 6-deficient mice show no abnormality of retinal cell organization and ganglion cell maturation. J Neurosci 19:2568-2579.

Vailati S, Hanke W, Bejan A, Barabino B, Longhi R, Balestra B, Moretti M, Clementi F, Gotti C (1999) Functional alpha6-containing nicotinic receptors are present in chick retina. Mol Pharmacol 56:11-19.

Vaney DI (1984) "Coronate" amacrine cells in the rabbit retina have the "starburst" dendritic morphology. Proc R Soc Lond B Biol Sci 220:501-508.

Vardi N, Masarachia PJ, Sterling P (1989) Structure of the starburst amacrine network in the cat retina and its association with alpha ganglion cells. J Comp Neurol 288:601-611.

Voigt T (1986) Cholinergic amacrine cells in the rat retina. J Comp Neurol 248:19-35.

Wassle H, Boycott BB (1991) Functional architecture of the mammalian retina. Physiol Rev 71:447-480.

West Greenlee MH, Finley SK, Wilson MC, Jacobson CD, Sakaguchi DS (1998) Transient, high levels of SNAP-25 expression in cholinergic amacrine cells during postnatal development of the mammalian retina. J Comp Neurol 394:374-385.

Wingate RJ, Thompson ID (1994) Targeting and activity-related dendritic modification in mammalian retinal ganglion cells. J Neurosci 14:6621-6637.

Wong RO, Collin SP (1989) Dendritic maturation of displaced putative cholinergic amacrine cells in the rabbit retina. J Comp Neurol 287:164-178.

Wong RO, Herrmann K, Shatz CJ (1991) Remodeling of retinal ganglion cell dendrites in the absence of action potential activity. J Neurobiol 22:685-697.

Wong ROL (1999) Role of retinal waves in visual system development. Annu Rev Neurosci 22:29-47.

Wong WT, Wong RO (2000) Rapid dendritic movements during synapse formation and rearrangement. Curr Opin Neurobiol 10:118-124.

Wong WT, Sanes JR, Wong ROL (1998) Developmentally regulated spontaneous activity in the embryonic chick retina. J Neurosci 18:8839-8852.

Wong WT, Myhr KL, Miller ED, Wong RO (2000) Developmental changes in the neurotransmitter regulation of correlated spontaneous retinal activity. J Neurosci 20:351-360.

$\mathrm{Xu} \mathrm{W,} \mathrm{Gelber} \mathrm{S,} \mathrm{Orr-Urtreger} \mathrm{A,} \mathrm{Armstrong} \mathrm{D,} \mathrm{Lewis} \mathrm{RA,} \mathrm{Ou} \mathrm{CN,}$ Patrick J, Role L, De Biasi M, Beaudet AL (1999a) Megacystis, mydriasis, and ion channel defect in mice lacking the alpha3 neuronal nicotinic acetylcholine receptor. Proc Natl Acad Sci USA 96:5746-5751.

Xu W, Orr-Urtreger A, Nigro F, Gelber S, Sutcliffe CB, Armstrong D, Patrick JW, Role LW, Beaudet AL, De Biasi M (1999b) Multiorgan autonomic dysfunction in mice lacking the beta 2 and the beta4 subunits of neuronal nicotinic acetylcholine receptors. J Neurosci 19:9298-9305.

Young RW (1984) Cell death during differentiation of the retina in the mouse. J Comp Neurol 229:362-373.

Yuste R (1997) Spontaneous activity in the developing CNS. Semin Cell Dev Biol 8:1-4.

Yuste R, Peinado A, Katz LC (1992) Neuronal domains in developing neocortex. Science 257:665-669.

Zhou ZJ (1998) Direct participation of starburst amacrine cells in spontaneous rhythmic activities in the developing mammalian retina. J Neurosci 18:4155-4165.

Zhou ZJ, Zhao D (2000) Coordinated transitions in neurotransmitter systems for the initiation and propagation of spontaneous retinal wave. $\mathbf{J}$ Neurosci 20:6570-6577.

Zoli M, Le Novere N, Hill Jr JA, Changeux JP (1995) Developmental regulation of nicotinic ACh receptor subunit mRNAs in the rat central and peripheral nervous systems. J Neurosci 15:1912-1939.

Zoli M, Picciotto MR, Ferrari R, Cocchi D, Changeux JP (1999) Increased neurodegeneration during ageing in mice lacking high-affinity nicotine receptors. EMBO J 18:1235-1244. 